\title{
PENERAPAN COGNITIVE BEHAVIOR THERAPY BERBASIS ISLAM BAGI PECANDU ALKOHOL
}

\author{
Fahrurrazi, Nurjannah \\ Universitas Islam Negeri Sunan Kalijaga Yogyakarta \\ E-mail: fahrurrazi824@gmail.com
}

\begin{abstract}
Therapy for alcoholics with the use of cognitive behavior-based Islam shows the results of a progressive. This study aims to obtain a comprehensive overview of the application of cognitive behavior therapy-based Islam in helping individuals overcome alcohol addiction. This study uses a qualitative research method is phenomenological. Participant research is an alcoholic. Data collection was performed by the method of triangulation, namely in-depth interviews (depth interviews) face to face with the observation and scale. Procedure the study was conducted with three step, namely the preparatory stage of the study, the implementation phase of the research, and the last stage of the evaluation of the results of the research. As for the results of the study showed that the application of cognitive behavior therapy-based Islam on individuals who experience addiction to alcohol showed significant changes in cognition, emotions and behavior of participants. Through the technique of cognitive restructuring, cognition participants who distorted changed to be more rational. Participants are able to set a good lifestyle, independent in work, respect people around and back to the right path in accordance with the teachings of Islam. a change in cognition in participants encourage the reduction behavior of consuming alcohol.
\end{abstract}

Keywords: Cognitive behavior therapy-based Islami; alcoholics

\begin{abstract}
ABSTRAK
Terapi bagi pecandu alkohol dengan menggunakan cognitive behavior therapy berbasis Islam menunjukkan hasil yang progresif. Penelitian ini bertujuan untuk mendapatkan gambaran menyeluruh dari penerapan cognitive behavior therapy berbasis Islam dalam membantu individu mengatasi kecanduan alkohol. Penelitian ini menggunakan metode penelitian kualitatif bersifat fenomenologis. Partisipan penelitian adalah seorang pecandu alkohol. Pengumpulan data dilakukan dengan metode triangulasi yakni wawancara mendalam (depth interview) secara face to face dengan observasi dan skala. Prosedur penelitian dilakukan dengan tiga tahap, yaitu tahap persiapan penelitian, tahap pelaksanaan penelitian, dan terakhir tahap evaluasi hasil penelitian. Adapun hasil penelitian menunjukkan bahwa penerapan cognitive behavior therapy berbasis Islam pada individu yang mengalami kecanduan alkohol menunjukkan perubahan yang signifikan pada kognisi, emosi dan perilaku partisipan. Melalui teknik cognitive restructuring, kognisi partisipan yang terdistorsi berubah menjadi lebih rasional. Partisipan mampu mengatur pola hidup yang baik, mandiri dalam bekerja, menghormati orang di sekitarnya dan kembali ke jalan yang benar sesuai dengan ajaran Islam. adanya perubahan kognisi pada partisipan mendorong berkurangnya perilaku mengkonsumsi alkohol.
\end{abstract}

Kata kunci: Cognitive behavior therapy berbasis Islami; Pecandu alkohol

\section{PENDAHULUAN}

Perilaku mengonsumsi alkohol bukanlah sebuah fenomena baru. Jika menilik sejarah, alkohol merupakan bagian dari tatanan sosial dan budaya masyarakat non-muslim seperti Yahudi dan kristen 
yang secara aktif dipromosikan dalam berbagai keadaan baik yang sifatnya sosial, budaya maupun agama (Charro Baena et al., 2019). Sementara dalam ajaran Islam, Allah memberikan larangan kepada hamba-Nya untuk mendekati khamr (alkohol) lebih-lebih

jika mengonsumsinya. Akan tetapi melihat realitas sosial yang ada banyak dari kalangan muslim yang mengonsumsinya mulai dari anak-anak, remaja, dewasa bahkan orang tua. Alkohol sebagaimana yang dijelaskan dalam peraturan menteri perdagangan No. 20 tahun 2014 adalah cairan yang mengandung unsur etanol dan zat karbohidrat yang diperoleh melalui fermentasi dan destilasi (Lestari, 2016). Dalam Islam, nama lain dari alkohol yaitu khamr. Yang dimaksud dengan khamr adalah minuman yang mengandung unsur alkohol yang terbuat dari buah anggur yang kemudian disimpan dalam beberapa waktu (Rassool, 2016). Sedangkan alkoholik dimaknai sebagai sebuah kekacauan dan kerusakan jiwa individu yang diakibatkan oleh pemaksaan terhadap diri sendiri untuk mengonsumsi alkohol secara kontinyu. Sehingga penderita yang mengonsumsinya secara berlebihan dapat menjadikannya sebagai habit (Chaplin, 2002).

Dilansir dari CNN.com (2018) World Health organization (WHO) mengungkapkan sebanyak tiga juta orang di dunia meninggal disebabkan oleh perilaku mengonsumsi alkohol. Angkat tersebut setara dengan satu dari dua puluh kematian di sunia diakibatkan oleh tindakan tersebut. Lebih dari $75 \%$ kematian akibat alkohol terjadi pada lakilaki. Di indonesia sendiri pada tahun 2014 mengalami peningkatan, Badan narkotika Nasional (BNN) memperkirakan ada 3,2 juta orang di Indonesia mempunyai riwayat pengguna NAPZA diantaranya $46 \%$ adalah tindakan mengonsumsi alkohol (Maula \& Yuniastuti, 2018). Sebagai tambahan, data dari Badan Pusat Statistik (BPS) pada tahun 2015-1018 menemukan bahwa konsumen alkohol yang berusia lebih dari 15 tahun mengalami peningkatan dalam setiap tahunnya.

Nurwijaya dalam bukunya menjelaskan bahwa ada empat tingkatan dalam penggunan minuman beralkohol. Pertama, tingkat eksperimental (percobaan) yaitu suatu kondisi dimana alkoholik mengonsumsi alkohol pertama kali karena rasa penasaran atau keingin tahuannya terhadap minuman tersebut. Sejalan dengan kebutuhan perkembangannya yakni ingin merasakan sesuatu yang baru dalam hidupnya. Kedua, tingkat rekreasional (penyegaran) yaitu tindakan mengkonsumsi alkohol terjadi 
ketika hendak berkumpul dengan temantemannya dalam rangka merayakan ulang tahun, reuni atau memang sudah direncanakan, baik di kafe-kafe, pantai, rumah dan lain-lainnya. Ketiga, tingkat situasional (situasi) yaitu setiap peminum memiliki tujuan secara khusus antara yang satu dengan yang lainnya. Perilaku tersebut merupakan langkah guna menenangkan diri atau bentuk pelampiasan diri karena stres, depresi, galau atau sedang bermasalah dengan orang lain. Jika hal demikian terus dilakukan dapat mengakibatkan dirinya menjadi kecanduan. Keempat, tingkat adiksi (kecanduan) yaitu perilaku negkonsumsi alkohol sifatnya patologis sudah mulai dikerjakan secara berlanjut yang pada akhirnya memunculkan sebuah konflik, merusak peran dan fungsi di tengah masyarakat. Mengkonsumsi alkohol dalam jumlah yang banyak membuat individu menjadi ketergantungan fisik dan psikis (Nurwijaya, 2009).

Khamr atau yang biasa disebut alkohol sama sekali tidak mengenal status sosial, ekonomi maupun rentan umur. Anak-anak, remaja-dewasa bahkan orangtua sekalipun sudah banyak yang berkecimpung dalam mengkonsumsi alkohol. Mayoritas para alkoholik adalah usia remaja-dewasa, baik yang tinggal di desa-desa maupun kota, kaya atau miskin, bahkan yang mengenyam pendidikan atau tidak (Prasasti, 2017). Penelitian yang dilakukan oleh Banat dan Rossy tentang faktor-faktor penyebab orang mengkonsumsi alkohol. Mereka menyimpulkan bahwa ada dua faktor yang menyebabkan individu mengkonsumsi alkohol yaitu faktor internal dan eksternal. Faktor internal seperti ingin mencoba karena rasa penasaran dan perasaan senang. Sedangkan faktor eksternalnya adalah kurangnya pengawasan orangtua, pergaulan bebas, pelampiasan masalah, rendahnya percaya diri serta pengetahuan yang minim akan bahaya alkohol dan zatzat yang terkandung di dalamnya (Maula \& Yuniastuti, 2018).

Mengkonsumsi alkohol secara berlebihan merupakan gejala dari timbulnya kejahatan seperti pencurian, pemerkosaan, tawuran, pemerasan, kekerasan dalam rumah tangga (KDRT), atau bahkan sampai pada tindakan pembunuhan (Ilham, 2020). Akhir-akhir ini maraknya kasus tindak pidana kejahatan yang muncul di tengah masyarakat yang terjadi di kota-kota besar seperti Yogyakarta yang diakibatkan oleh minuman keras (Handrina, 2020). Dilansir dari tribunJogja.com, beberapa hari yang lalu terjadi pembuhunan oleh teman sendiri akibat dari mengkonsimsi alkohol. Selain memunculkan kejahatan, alkohol 
juga memiliki dampak negatif pada oragnisme individu. Pada tahap awal penggunaan dan penyalahgunaan yang berkepanjangan dapat mengakibatkan kerusakan pada otak dan menunjukkan pada kedua penyakit akut dan kronis (Pulido et al., 2014).

Untuk mengatasi atau bahkan mencegah maraknya perilaku mengkonsumsi alkohol yang memunculkan kasus-kasus yang marak terjadi saat ini maka perlu adanya perhatian yaitu dengan cara membantu individu atau seseorang yang kecanduan alkohol. Pendekatan agama dan spiritual tidak seharusnya diabaikan begitu saja dalam konseling dan psikoterapi karena membawa kesan positif terhadap klien (Sumari, 2014). Oleh karena itu cognitive behavior therapy berbasis Islam hadir untuk mengatasi kecanduan alkohol yang dialami oleh klien. Cognitive behavior berbasis Islam bukan saja memperbaiki pikiran yang negatif menjadi positif. Akan tetapi juga memperbaiki sikap, perilaku dan kepercayaan mereka.

Cognitive behavior therapy (CBT) dalam makna konvensional merupakan psikoterapi yang berfokus pada kognisi yang dimodifikasi secara langsung, yaitu ketika individu mengubah pikiran maladaptifnya maka secara tidak langsung juga mengubah tingkah lakunya yang tampak. Beck mengungkapkan bahwa salah satu tujuan utama CBT adalah untuk membantu individu dalam mengubah pemikiran atau kognisi yang irasional menjadi permikiran yang lebih rasional. Untuk memahami masalah yang dialami oleh klien dengan lebih tepat berdasarkan pendekatan cognitive behavior, maka perlu dilakukan analisa fungsional atau analisa masalah berdasarkan prinsip S-O-R-C (stimulus, organism, response, consequences) (Spiegler \& Guevremont, 2003). Untuk mempermudah pembaca dalam memahaminya, berikut disajikan dalam bentuk diagram:

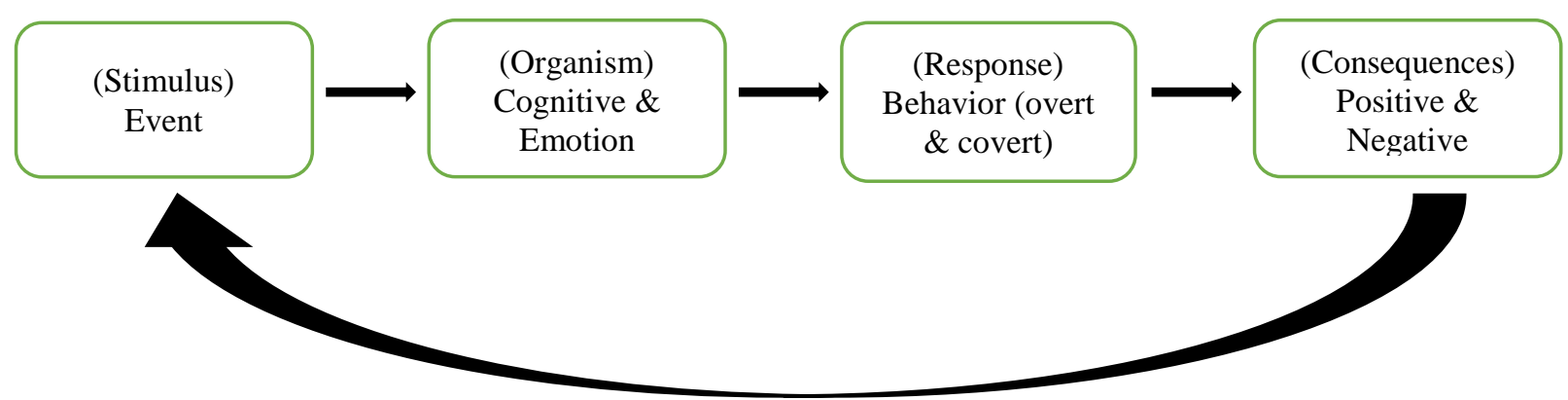


Keterangan:

Stimulus (S) : Peristiwa yang terjadi sebelum individu menunjukkan perilaku tertentu.

Organism (O): Partisipan dengan aspek kognisi dan emosi di dalamnya.

Response (R): Apa yang dilakukan oleh individu atau organism, sering juga disebut dengan perilaku, baik yang tampak atau tidak.

Consequences $(\mathbf{C})$ : Peristiwa yang terjadi setelah atau sebagai suatu hasil dari perilaku.

CBT berbasis Islam pada dasarnya menggunakan teknik-teknik yang dimiliki oleh CBT pada umumnya, namun yang membedakan terletak pada unsur-unsur keIslaman. Dalam CBT berbasis Islam dalam pelaksanaan intervensi menggunakan sumber utama agama Islam yaitu ayat-ayat al-Qur'an dan Hadist. Selain itu, keunikan untuk CBT berbasis Islam yaitu penggunaan eksplisit tradisi keagamaan konseli sendiri sebagai landasan untuk mengidentifikasi dan mengganti pikiran dan perilaku (Pearce et al., 2015). Sehingga dapat dipahami secara mendalam bahwa CBT berbasis Islam merupakan interkonseksi dari CBT konvensional dengan nilai-nilai ajaran Islam yang terdapat di dalam al-Qur'an dan Hadist dan diintegrasikan dalam proses konseling.

Beberapa penelitian sebelumnya yang membahas tentang terapi bagi pecandu alkohol dan NAPZA. Seperti dalam penelitiannya Puji Lestari menunjukkan bahwa pembinaan dan penyadaran korban penyalahgunaan NAPZA melalui metode Zikrullah. Zikrullah dimaksudkan sebagai alat penenang hati, penyembuhan segala penyakit hati, pembersih hati, dan sebagai alat peningkatan iman kepada Allah. Adapun materi rehabilitasi meliputi mandi malam atau mandi taubat, shalat-shalat wajib dan sunah, zikir, membaca Alqur'an, riyadlah, pengajian rutun mingguan dan bulanan, do'a-do'a, dan pembelajaran tentang keilmuan seperti Fiqh, Tauhid, Akhlak, dan Tashawuf (P. Lestari, 2012). Berbeda dengan penelitian yang dilakukan oleh Ina Noor dkk, menunjukkan bahwa Zikir asmaul husna bisa menjadi pengobatan yang efektif untuk meningkatkan pengendalian diri pecandu alkohol (Nafisa et al., 2017). Dalam penelitian lain yang menggunakan terapi ala barat guna mengatasi pecandu alkohol. Sebagaimana dalam penelitiannya Suri \& Liza, hasil penelitiannya menunjukkan bahwa terapi thought stopping menghentikan pikiran negatif sangat efektif dalam merubah proses pikir pada remaja pecandu minuman keras (Yani \& Putri, 2020).

Penelitian yang ada hanya menggunakan terapi zikir dan terapi asmaul husna untuk mengatasi kecanduan 
alkohol pada individu. Sementara penelitian lainnya hanya menggunakan terapi yang ditawarkan oleh orang barat. Sehingga peneliti mencoba untuk menggunakan pendekatan konvensional yang ditawarkan oleh orang barat yang kemudian di kombinasikan dengan nilainilai keIslaman. Hal ini yang menjadi pembeda dari penelitian-penelitian sebelumnya. Berdasarkan uraian di atas, maka peneliti tertarik untuk melihat bagaimana hasil penerapan cognitive behavior therapy (CBT) berbasis Islam pada individu yang mengalami kecanduan alkohol. Oleh karena itu tujuan dari treatment adalah untuk membantu individu yang mengalami kecanduan alkohol memperoleh wawasan untuk mengurangi durasi mengonsumsi alkohol sehingga perilaku konsumsi alkohol setidaknya terminimalisirkan atau bahkan terhentikan.

\section{METODE}

Penelitian ini menggunakan pendekatan kualitatif bersifat fenomenologis. Fenomenologi merupakan suatu metode yang bertujuan untuk mendeskripsikan, menelaah, serta memahami suatu kejadian yang dialami oleh individu berupa perubahan sikap maupun perilaku individu yang merasakan kejadian tersebut (Jhon W. Creswell, 2019). Dalam konteks ini pecandu alkohol.
Sebagai informan tunggal yang kecanduan alkohol, dengan kesepakatan mencantumkan inisial nama dalam penelitian. Subyek berusia 30 tahun, saat ini ia bekerja sebagai kuli bangunan. Subyek pertama kali mengkonsumsi alkohol ketika menginjak bangku SMA hingga saat ini. Kecanduannya terhadap alkohol ditunjukkan dari sikapnya dalam mengkonsumsi alkohol yaitu paling tidak 2-4 kali dalam seminggu.

Metode pengumpulan data dilakukan dengan metode triangulasi yakni wawancara mendalam (depth interview) secara face to face dengan observasi dan skala. Prosedur penelitian ini dikelompokkan dalam tiga tahap. Pertama tahap persiapan penelitian, kedua tahap pelaksanaan penelitian, dan ketiga tahap evaluasi hasil penelitian. Treatment akan dilakukan secara fleksibel yaitu tergantung ketersediaan atau kesiapan subyek. Jumlah pertemuan secara keseluruhan pelaksanaan intervensi adalah sebanyak 9 pertemuan dengan waktu masing-masing pelaksanaan intervensi adalah 90 menit. Waktu dan jumlah pertemuan akan disesuaikan berdasarkan dengan kebutuhan treatment pada proses konselingnya. Sehingga jumlah waktu yang dibutuhkan untuk pelaksanaan terapi adalah 4 minggu. 


\section{HASIL DAN PEMBAHASAN}

Hasil penelitian menunjukkan bahwa penerapan cognitive behavior therapy (CBT) berbasis Islam pada individu yang mengalami kecanduan alkohol menunjukkan adanya perubahan kognitif yang terdistorsi menjadi lebih rasional sehingga perilaku mengonsumsi alkohol menjadi berkurang. Dalam pelaksanaan cognitive behavior therapy berbasis Islam, klien mengalami distorsi kognitif yang sama seperti jumping to conclusion yaitu hasil negatif diperoleh dari bukti yang tidak relevan dan magnification yakni memandang sesuatu lebih jauh atau lebih penting dari yang sebenarnya. Klien mengalami absolute term yakni berpikir harus. Klien menganggap bahwa mengkonsumsi alkohol membuat dirinya menjadi tenang, melupakan masalah sejenak, membuat fisik menjadi lebih bertenaga, membangun solidaritas dengan orang lain serta membuat tidur menjadi lebih nyaman. Pikiran-pikiran klien yang seperti ini disebebkan karena argumennya mengenai alkohol hanya melihat dari sisisisi kesenangan sesaat saja tanpa memikirkan dampak negatif yang ditimbulkan oleh alkohol itu sendiri serta melalaikan perintah al-Qur'an terkait dengan pelarangan mengkonsumsi alkohol serta ancaman-ancaman yang termaktub dalam Hadist bagi orang yang mengkonsumsi alkohol.

Setelah treatment dilakukan kepada klien, klien menunjukkan adanya perubahan kognisi yang terdistori menjadi lebih rasional melalui teknik cognitive restructuring yang dikombinasikan dengan modifikasi perilaku dan nilai-nilai keislaman untuk menguatkan perilaku yang diinginkan atau kembali ke jalan yang benar sesuai dengan ajaran Islam. berikut ini merupakan perubahan yang dialami oleh klien setelah terapi (lihat Tabel I): 
Tabel 1. Rekapitulasi Data hasil Penerapan CBT pada Klien

\begin{tabular}{|c|c|c|c|}
\hline \multirow[t]{2}{*}{ KET } & \multicolumn{3}{|c|}{ Klien } \\
\hline & Sebelum Terapi & Proses Terapi & Sesudah Terapi \\
\hline Teknik CBT & \multicolumn{3}{|c|}{ Cognitive Restructuring } \\
\hline Attending/Opening & $\begin{array}{l}\text { Tertutup } \\
\text { Tanpa Ekspresi } \\
\text { Gugup }\end{array}$ & $\begin{array}{l}\text { Perkenalan } \\
\text { Berkomunikasi secara } \\
\text { verbal dan non verbal } \\
\text { mulai membangun } \\
\text { hubungan dengan klien } \\
\text { guna menciptakan } \\
\text { rapport. }\end{array}$ & $\begin{array}{l}\text { Open minded } \\
\text { Merasa dihargai } \\
\text { Responsif } \\
\text { Merasa Aman }\end{array}$ \\
\hline $\begin{array}{l}\text { Tanggapan sebelum } \\
\text { dan sesudah Terapi }\end{array}$ & $\begin{array}{l}\text { Menganggap bahwa } \\
\text { tidak ada yang berani } \\
\text { memarahinya. } \\
\text { Tidak takut dengan } \\
\text { hukum Allah, orang } \\
\text { tua, dan tokoh } \\
\text { masyarakat. } \\
\text { Tidak disiplin waktu } \\
\text { Pola hidup yang } \\
\text { tidak sehat }\end{array}$ & $\begin{array}{l}\text { Berusaha meyakinkan } \\
\text { diri untuk } \\
\text { menghilangkan } \\
\text { kebiasaan } \\
\text { mengkonsumsi alkohol } \\
\text { oleh klien, dengan } \\
\text { menerapkan materi } \\
\text { CBT serta menanamkan } \\
\text { nilai-nilai keIslaman } \\
\text { yaitu mengajak klien } \\
\text { kembali ke jalan yang } \\
\text { benar sesuai dengan } \\
\text { syariat Islam, konselor } \\
\text { juga tidak henti- } \\
\text { hentinya berdo'a } \\
\text { supaya klien } \\
\text { mendapatkan hidayah. }\end{array}$ & $\begin{array}{l}\text { Mulai ada rasa } \\
\text { takut terhadap } \\
\text { orangtua dan } \\
\text { ancaman Allah } \\
\text { Bersikap sopan } \\
\text { santun dengan } \\
\text { orang tua, saudara } \\
\text { dan lingkungan } \\
\text { masyarakat } \\
\text { Lebih rajin dalam } \\
\text { bekerja } \\
\text { Memenuhi } \\
\text { panggilan Allah } \\
\text { seperti shalat, } \\
\text { puasa, dan ikut } \\
\text { serta dalam } \\
\text { kegiatan sosial } \\
\text { masyarakat }\end{array}$ \\
\hline Durasi konsumsi & \multicolumn{3}{|c|}{ 3-4 jam setiap kali minum } \\
\hline Frekuensi konsumsi & \multicolumn{3}{|c|}{ 2-4 kali dalam seminggu } \\
\hline $\begin{array}{l}\text { Perubahan yang } \\
\text { dialami }\end{array}$ & \multicolumn{3}{|c|}{ Progresif } \\
\hline Follow Up & \multicolumn{3}{|c|}{$\begin{array}{l}\text { Mampu mengatur pola hidup yang baik } \\
\text { Lebih disiplin waktu, baik dalam bekerja maupun ibadah } \\
\text { Mampu menghargai keluarga dan masyarakat sekitarnya } \\
\text { Mampu menerima ajaran Islam terkait dengan pelarangan } \\
\text { mengkonsumsi alkohol serta dampak negatif yang ditimbulkan bagi } \\
\text { kesehatan }\end{array}$} \\
\hline
\end{tabular}

Hasil penelitian menunjukkan bahwa cognitive behavior therapy berbasis islam dapat diterapkan untuk mengurangi durasi individu mengkonsumsi alkohol pada individu yang mengalami kecanduan alkohol. Berbeda dengan penelitian lain bahwa kecanduan alkohol dapat diatasi dengan menggunakan terapi zikir (P. Lestari, 2012). 
Penelitian lain juga menunjukkan bahwa terapi zikir asmaul husna dapat pula menjadi pengobatan yang efektif untuk meningkatkan pengendalian diri pecandu alkohol (Nafisa et al., 2017). Tidak hanya itu, terapi thougt stopping sebagai mana yang ditawarkan oleh orang barat bahwa terapi tersebut dapat menghentikan pikiran negatif sangat efektif dalam merubah proses pikir pada remaja pecandu minuman keras (Yani \& Putri, 2020).

Aaron Beck \& Ellis mengungkapkan bahwa cognitive behavior therapy dapat diterapkan jika disebabkan oleh kognisi yang terdistorsi, dengan tujuan terapi adalah untuk menantang kognisi terdistorsi agar dapat dimodifikasi menjadi lebih rasional sehingga memunculkan perilaku yang adaptif (Spiegler \& Guevremont, 2003). Partisipan penelitian mengalami kecanduan alkohol karena adanya beberapa distorsi kognitif. Distorsi kognitif yang paling sering muncul pada partisipan yaitu memandang sesuatu lebih jauh atau lebih penting dari yang sebenarnya (Spiegler \& Guevremont, 2003). Partisipan memandang bahwa hanya alkohol yang membuat dirinya menjadi lebih tenang, melupakan sejenak masalah yang ada, menjadi lebih bertenaga dan membangun solidaritas sosial.

Perilaku individu yang menjadi pecandu alkohol memiliki efek negatif, tidak hanya pada individu itu sendiri akan tetapi juga untuk masyarakat sekitarnya. Oleh sebab itu, Islam sebagai agama rahmatan lil 'alamin dalam ilmu psikosufistik sudah dijelaskan secara ekplisit bahwa individu dengan pengendalian diri dengan baik akan muncul sebagai rasa keamanan bagi orangorang disekitarnya. Orang yang memberikan kemanan bagi orang lain berarti mereka beriman kepada al-Qur'an. Pecandu alkohol cenderung membuat orang disekitarnya merasa tidak aman dan nyaman. Karena itu CBT berbasis Islam menjadi alat untuk mengubah pikiran dan perilaku di lingkungan sosial yang secara psikologis aman (Lindgren et al., 2014).

Perilaku mengonsumsi alkohol dilakukan sebagai sebuah upaya untuk mengatasi problem emosional seperti depresi, angry, anxiety, bosan, frustasi dan masalah pernikahan. Akan tetapi, konsumsi alkohol secara terus menerus mengakibatkan hilangnya memori, mabuk dan mati rasa. Tidak hanya itu, mengonsumsi alkohol akan berdampak terhadap kerusakan fisik yang berkepanjangan, seperti sakit perut, jantungan, kanker, kerusakan otak serta sirosis hati. Ada juga risiko kecelakaan, pembunuhan dan bunuh diri. Alkohol juga memiliki dampak negatif yang sangat besar bagi pelakunya seperti pada kesehatan mental dan dapat merusak 
kondisi yang ada seperti depsresi, kecemasan, perilaku mengganggu, kekerasan, kecelakaan serta perdebatan (Rassool, 2019). Konsumsi minuman keras atau istilah tradisionalnya adalah tuak dapat meningkatkan resiko kejadian obesitas sentral pada laki-laki yang dewasa (I.K. Sudiana et al., 2016).

\section{PENUTUP}

Treatmen yang dilakukan telah menunjukkan terjadinya perubahan pada kognitif yang terdistorsi menjadi lebih rasional terutama pada saat klien menghadapi situasi yang mendorong dirinya untuk mengkonsumsi alkohol. Hal ini terlihat dari automatic thought klien bahwa alkohol tidak bisa membuat dirinya menjadi lebih tenang, sehat dan aman.

Saran bagi klien penelitian untuk tetap menerapkan kegiatan-kegiatan yang telah diberikan oleh konselor sehingga dapat mempertahankan atau meningkatkan perubahan perilaku yang telah dicapai pada saat intervensi dan terbentuk perilaku yang adaptif. Hal demikian dikarenakan kemungkinan individu yang mengalami relapse. Klien lebih mampu lagi untuk mengeksplorasi kegiatan lain yang disukainya guna menguatkan perubahan perilaku mengkonsumsi alkohol. Kemudian bagi keluarga atau orangtua klien dapat memberikan perhatian dan pujian untuk membantu terbentuknya prilaku yang diinginkan. Orangtua diharapkan dapat mengawasi atau mengontrol perilaku anak. Karena kurangnya kontrol atau pengawasan orangtua dapat menimbulkan sebuah permasalahan.

\section{DAFTAR PUSTAKA}

Chaplin, J. P. (2002). Kamus Lengkap Psikologi (K. Kartono (ed.); Edisi Kede). Rajawali Pers.

Charro Baena, B., Meneses, C., Caperos, J. M., Prieto, M., \& Uroz, J. (2019). The Role of Religion and Religiosity in Alcohol Consumption in Adolescents in Spain. Journal of Religion and Health, 58(5), 1477-1487. https://doi.org/10.1007/s10943-0180694-z

Handrina, E. (2020). Pemidanaan Terhadap Pelaku Tindak Pidana Yangdisebabkan Pengaruh Minuman Keras Di Kabupatensolok Selatan Di Tinjau Secara Sosiologi. Jurnal Enslikopediaku, 2(1), 14-19. https://www.golder.com/insights/bloc k-caving-a-viable-alternative/

I.K. Sudiana, I.W.G. Artawan Eka Putra, \& P.P. Januraga. (2016). Konsumsi Tuak Meningkatkan Risiko Obesitas Sentral pada Pria Dewasa di Karangasem, Bali. Public Health and Preventive Medicine Archive, 4(2), 134-142.

Ilham, M. A. (2020). Pengaruh Minuman Keras Terhadap Timbulnya Kejahatan Di Kota Makassar. Indonesia Journal of Criminal Law ( IJoCL ), 1(1), 6576.

Jhon W. Creswell. (2019). RESEARCH DESIGN Pendekatan Metode 
Kualitatif, Kuantitatif, dan Campuran (ke-IV). Pustaka Pelajar.

Lestari, P. (2012). Metode Terapi Dan Rehabilitasi Korban Napza Di Pondok Pesantren Suryalaya Tasikmalaya. DIMENSIA, 6(1), 1-16.

Lestari, T. R. P. (2016). Menyoal Pengaturan Konsumsi Minuman Beralkohol Di Indonesia Questioning the Regulation on Consumption of Alcoholic Beverages in Indonesia. Aspirasi, 86, 127-141.

Lindgren, K. P., Neighbors, C., Westgate, E., \& Salemink, E. (2014). Selfcontrol and implicit drinking identity as predictors of alcohol consumption, problems, and cravings. Journal of Studies on Alcohol and Drugs, 75(2), 290-298.

https://doi.org/10.15288/jsad.2014.75. 290

Maula, L. K., \& Yuniastuti, A. (2018). Analisis Faktor Yang Mempengaruhi Penyalahgunaan dan Adiksi Alkohol pada Remaja di Kabupaten Pati. Public Health Perspective Journal, 2(2), 168-174.

Nafisa, I. N. K., Nashori, F., \& Rumiani. (2017). Effectiveness of Asmaul Husna dhikr therapy to enhance the self control of Alcohol Abuser. Indonesian Journal of Medicine and Health, 8(3), 154-163.

Nurwijaya, H. da I. (2009). Bahaya Alkohol dan Cara Mencegah Kecanduannya. Erlangga.

Pearce, M. J., Koenig, H. G., Robins, C. J., Nelson, B., Shaw, S. F., Cohen, H. J., \& King, M. B. (2015). Religiously integrated cognitive behavioral therapy: A new method of treatment for major depression in patients with chronic medical illness. Psychotherapy, 52(1), 56-66. https://doi.org/10.1037/a0036448
Prasasti, S. (2017). Kenakalan remaja dan faktor penyebabnya. Seminar Nasional Bimbingan Dan Konseling, 1(1), 28-45.

Pulido, J., Indave-Ruiz, B. I., ColellOrtega, E., Ruiz-García, M., Bartroli, M., \& Barrio, G. (2014). Estudios poblacionales en España sobre daños relacionados con el consumo de alcohol. Revista Espanola de Salud Publica, 88(4), 493-513. https://doi.org/10.4321/S113557272014000400005

Rassool, G. H. (2016). Islamic Counseling: An introduction to theory and practice. Routledge.

Rassool, G. H. (2019). Konseling Islami: Sebuah pengantar kepada Teori dan praktik. Pustaka Pelajar.

Spiegler, \& Guevremont. (2003). Contemporary Behavior Therapy (4th ed.). . Thomson Wadsworth.

Sumari, M. (2014). Teori Konseling dan Psikoterapi. universiti Malaya.

Yani, S., \& Putri, L. (2020). Penerapan Terapi Thought Stopping Untuk Mengatasi Remaja Pecandu Minuman Keras. Journal of Nursing and Public Health, 8(2), 87-90. 